\title{
Narratives about Migratory Experiences and Homeland among the Albanians from the Republic of Macedonia
}

DOI 10.17234/9789531756525.5

Ivaylo Markov

Institute of Ethnology and Folklore Studies with Ethnographic Museum, Bulgarian

Academy of Sciences

Moskovska Str. 6A, 1000 Sofia, Bulgaria

ivaylo.markov@iefem.bas.bg

The article focuses on two groups of migratory narratives collected by the author among the Albanian labour migrants from the Republic of Macedonia. The first group refers to temporary migration, i.e. to migrants going to work abroad, but with the idea that after a while they will return to their place of origin. The second reflects the changes in migratory trends showing the experience as well as the perceptions about those who have settled abroad and have raised their children and grandchildren there. The main aim of the article is to critically examine these different narratives and stories about migratory experiences, migrants' attitudes toward their place of origin and perceptions about where "home" is.

Keywords: Albanians, labour mobility, family migration, migratory narratives, homeland

\section{Introduction: a brief history of the migration of Albanians from Macedonia}

I $\mathrm{n}$ the last few decades, the total number of people moving from one place to another, trying to make a living, is steadily increasing. ${ }^{1}$ There is no doubt that human mobility and migration have played a very significant role in the contemporary world and societies of the second half of the $20^{\text {th }}$ century. The absolute number of moving people is not so important, but the multifarious nature and characteristics of contemporary migration are determinative of its significance in public discourse and the way it shapes and re-shapes both sending and receiving migrant societies (King 2012: 6). In their summary of the characteristics of

1 The reports and data about the trends in migration stock of the United Nations show that, in 2015, the number of international migrants worldwide reached 244 million, up from 175 million in 2000, 99 million in 1980 and 75 million in 1960. The share of international migrants in the world population is as follows: $2.5 \%$ in $1960,2.2 \%$ in $1980,2.8 \%$ in 2000 and $3.3 \%$ in 2015 (United Nations 2006: 1-2; United Nations 2016: 1-2). 
contemporary migration (globalization, acceleration, differentiation, feminization and politicization) Stephen Castles and Mark Miller (2003) formulate the notion of "the age of migration". In this respect, we face a considerable variety of ethnic and cultural groups taking part in migratory processes, various directions of movements and improved means of transportation, communications and access to information; political and public perceptions about migration and migrants are contradictory. It should not be neglected that temporary or pendulum movements are interlaced with the migration of people permanently moving from their places of origin.

Labour mobility away from the birth place, practicing various activities with the aim of earning means for living, has been known for centuries among the population in the broad area of the Balkans. In the region, these movements are known as gurbet, kurbet; and in the South Slavic languages the term pecalba is used synonymously ${ }^{2}$ (Hristov 2015: 31). At the end of the $19^{\text {th }}$ and the beginning of the $20^{\text {th }}$ century, gurbet/pećalba was a typical male occupation and usually referred to seasonal or temporary work: men left their place of origin and moved abroad making a living for their families remaining at home. They were engaged in different types of economic activities, either in the agrarian industry, such as harvesting and sheep breeding, or in the craft industry, like construction, confectionery and pottery (Palairet 1987: 25-37). Such labour mobility to closer (in the Balkan area) or more distant localities (Asia Minor, Egypt, Romania, etc.) was also known among the Albanian population inhabiting territories located today in the western part of the Republic of Macedonia (see Markov 2012). The new political borders in the Balkans after the Balkan Wars and World War I, the increasing restrictive national legislation in particular countries, combined with a complex political environment in the most Balkan countries, resulted in a drastic decrease in transborder labour mobility (Hristov 2015: 42-43). During the later interwar period and the first decade after World War II, migrant labourers from Macedonian territories redirected their routes to the north, within the borders of Yugoslavia itself, ${ }^{3}$ and then to the east (Palairet 1987: 34-35); the Albanian gurbetzhinjtë (migrant labourers) were no exception (Markov 2010: 303-304).

In this article, the subject of research interest, however, is more recent Albanian migration (the last five decades) in search of livelihood and improving living conditions. The Second World War and its aftermath proved to be a turning point in the process of their labour movements, and during the subsequent post-war

2 The word gurbet derives from Arabic and in the Balkan languages comes through Turkish. It means "abroad", somewhere far from one's home. Pečalba literary means "gain", "to gain for a living” (Константинов 1964: 14-15; Hristov 2015: 31).

3 Before the war this was the Kingdom of Yugoslavia, and after that the Yugoslav federation. 
decades they changed vastly in size, intensity, characteristics, and main destinations. In the second half of 1960s, Yugoslavia concluded recruitment treaties regulating the temporary employment of Yugoslav workers with various Western European countries which were still enjoying its post-war economic boom, and migrant labour was very much in demand (Ivanović 2012: 31-70; Novinšćak 2009; Fassmann and Reeger 2008: 21-28; Gross 2006: 9-10). Thus, the Yugoslav Federation became a very active participant in the guest worker programmes of post-war Europe. Macedonia was one of the Yugoslav republics which experienced a large-scale migration of mostly unskilled workers in the following decades. And many of them were, namely, Albanians who were seeking better livelihoods working abroad. ${ }^{4}$

Although each receiving European country pursued its own migratory policy, there were several common elements. The recruitment of workers, the working conditions, and the social insurance were regulated by the bilateral agreements mentioned above. Migrants were guest workers (or, according to the commonly accepted German term, "Gastarbeiters"). They were considered temporary labourers, who worked for a limited period of time according to residence and labour permits (which were often valid for specific jobs and areas), and afterwards they would return to their home countries. If there were still need for labour force, new workers could come. Entry of dependants was strongly restricted (Castles and Miller 2003: 69-72). Under these structural conditions, the first Albanian migrant workers coming from Macedonia were solely men, and migration was also perceived by most of them as temporary.

These movements did not differ from the gurbet pattern of labour mobility, known for centuries in the region, as I already mentioned above. The late 1960s were a time when labour mobility among Albanian population started to change vastly in size, intensity, characteristics and main work destinations, and working abroad became a very important source of livelihoods for many Albanian family households. The economic and social transnational practices were entirely oriented towards the villages of origin in Macedonia.

A change occurred in the structural conditions of this labour mobility in the mid-1970s. The oil crisis of 1973 and the subsequent economic recession affected the host European countries so that they needed fewer foreign workers. Contrary

According to census data there were 56,449 Macedonian citizens abroad in 1971 (3.4\% of the total population), 100,922 (5.3\%) in 1981 and 173,611 (8.3\%) in 1994. Compared to these data, the percentage of Albanians (of the entire Albanian population in Macedonia) working and living abroad was bigger - 4.2\% in 1971, 5.9\% in 1981 and 10.7\% in 1994 (Јанеска 2001: 178-180, 201-204). Unfortunately, the 2002 Census was conducted according to a different methodology and counted only those Macedonian citizens residing abroad up to one year. Therefore, these data are incomparable to the previous ones. 
to expectations, however, and in spite of the restrictions put in place, migration continued. In fact, the freeze on recruitment of new guest workers stimulated the prolonged stay of those already working there. It was a precondition for their settlement. The governments in the receiving Western European countries initially opposed family reunion, but with little success. After long debates, it was accepted as a human right, but was made possible under specific conditions concerning adequate accommodation, sufficient resources, health insurance etc. (Castles and Miller 2003: 79-80). Thus, as a result of the changed macro conditions (economic, political and social) in the second half of the 1980s in Yugoslavia and especially during the 1990s (when Macedonia became an independent state), the process of "family reunion" gradually gained speed among the Albanian migrants as well, and many of them brought their families to the host countries (see also Iseni 2013: 234). The unfavourable political and economic prospects in Macedonia during this period explain why the desire to migrate abroad increased. The established culture of migration played a crucial role during the 1990s and 2000s in the manner that migration continued with high intensity, despite the limited opportunities for going abroad due to the strong visa restrictions for all former Yugoslav citizens. This time, however, the processes of family reunion and family formation caused an increase in the number of women and children abroad (Markov 2013: 250-251)..$^{5}$ Living away from the home country with the family changed migrants' priorities: integration in receiving society came to the fore.

It is significant that, during the last three decades, "family migration" existed simultaneously with the migration of single men. On the basis of ethnographic fieldwork materials I collected, two main categories of migratory experience and narratives can be distinguished. The first one refers to temporary migration, i.e. to migrants going to work abroad without their wives and children, but planning to return to their place of origin. The second reflects the changes in migratory trends showing the experience as well as the perceptions about those who have settled abroad and have raised their children and grandchildren there. The main aim of the paper is to examine these different narratives and stories about migratory experience, migrants' attitudes toward the place of origin and perceptions where "home" is.

According to the Macedonian census data, the number of migrant family members living with them abroad in 1971 was barely 2,016 (3.6\%), but it grew to $42,958(42.6 \%)$ in 1981 and to 87,079 (49.8\%) in 1994. Among the Albanians, however, the number of family members in 1981 was less than the average - around 30\%; in 1994 this percentage was already 49.9\% (Јанеска 2001: 201-203). 


\section{Methodological notes}

The article is based on ethnographic fieldwork ${ }^{6}$ conducted in the western part of Macedonia, where the Albanian population is concentrated, more particularly in selected villages in the municipalities of Skopje, Tetovo, Tearce and Struga. Four field research sessions of 10-15 days each, as well as several shorter occasional field trips, were carried out in this area from 2008 to 2010. A set of 35 interviews with 43 interlocutors was conducted in both rural and urban locations. In addition, the research benefited from several informal conversations in the study locations. The respondents were migrants who, at the time of the interview, were on return visits in their places of origin or former migrants, who had worked abroad, but returned to Macedonia. Among the first group of respondents, at the moment of the interview, there were people who planned to get back to their places of origin, as well as those who saw their future work and family life possible only out of Macedonia. As to the returnees, some of them planned to work again abroad for a certain period of time. Others had the idea to go with their families next time. There were also people who declared that they would never go to work abroad again.

All my interlocutors were Muslim Albanians. Their age ranged from 18 to 75 years, most of them attended primary and secondary school, and a few had higher education. Almost all my interviewees were men. This is largely a reflection of the patriarchal context of the Albanian Muslim community in western Macedonia, within which young unmarried men like me are allowed to access only men's places. Merely three short conversations with Albanian women were conducted, but in the presence of their male companions - either husband or friend - with whom I established a close relationship of trust. Thus, this text generally presents the male point of view.

Most of the ethnographic interviews I conducted were a combination of semistructured and biographical (life history) narratives. The life-history approach is very valuable in studying processes, social changes and everyday life, especially in cases when the archives are incomplete or missing (Thompson 1978). Life histories allow us to observe the changes in the cultural and social experience of the individuals, their points of view and daily cultural practices, and in the meanings people invest in their actions (Roberts 2002: 21). This approach takes into consideration the fact that life histories are subjective, but finds them valuable as they reveal the respondents' opinions, dispositions and attitudes (Lieblich et al. 1998). At the same time, the respondents' "versions" are juxtaposed to information from other secondary sources, statistical data and scientific interpretations.

It was part of my work on a doctoral dissertation under the title "Contemporary Labour Migrations of Albanians from Macedonia". The dissertation was defended successfully at the Institute of Ethnology and Folklore Studies with Ethnographic Museum (IEFSEM) in Sofia on July 18, 2011. 


\section{Narratives about temporary migration}

As my interlocutors pointed out, the causes and motives for migration, are various, but a common motivation is the economic striving to earn enough to maintain basic needs of life and improve the household standard of living. Before leaving their birth villages, almost all of my respondents, temporary workers, lived in extended family households. ${ }^{7}$ A large number of them were already married and some had children. Their wives and children stayed behind and the husbands' parents, unmarried brothers or sisters, who in most cases lived together in extended rural families, took care of them. Children's rearing is the women's responsibility, but all the decisions concerning marriage, education, visiting relatives, taking part in rituals and any activities that could affect the family prestige are prerogatives of the household's head. The migrants' wives and children are very cautious about their behaviour in order to maintain their unblemished reputation. Usually, they are put under close scrutiny by the local community and according to its common moral norms are expected to be quite humble and modest in their public actions. This behaviour is required in order to guarantee the honour of both, the man working abroad and the family in the village in Macedonia (for Kosovo, cf. Reineck 1991: 135).

"The young bride left here does not dare to dress as young. Because her husband is absent. She must be dressed as some old woman. If she puts on new clothes, she would be laughed at, she would be told she is unfaithful, she is a prostitute. Even now those women are put under strong observation and in a very difficult position." (Man, born in 1947; worked in Serbia, currently lives as a pensioner in Zhelino near Tetovo)

Many of my interlocutors often related emotional heart-breaking stories about the modest socio-economic conditions in which they live abroad in order to save money. Seven to ten workers usually live together in a small flat and divide the rent. Many of them work overtime and even during the weekends, to double their daily wages. Migrants restrain their consumption to a minimum. They shop at discount stores, avoid pubs or restaurants, and spend money only for the barest necessaries. As suggested by Bashkim Iseni, in the case of the Kosovar Albanians in Switzerland, temporal migrants live "on the margins of the host country, leading a parallel social life to its mainstream populations" (Iseni 2013: 231). In most cases temporary migrants speak with a deep pain about the years they spent abroad. They define this period as the hardest time of their life.

Such a family situation was particularly applicable for migrant workers from the first migration waves from the late 1960s to the early 1980s. Such cases, however, can be observed even today. 
"Often these people come back home. When he digs a channel or a construction site falls down - sometimes the man is sent back in a coffin. Therefore, the gurbet is a running wound for us. Nobody wants it. However, a man is forced to leave his home and to go to gurbet. It is not at his will, but a compulsion." (Man, born in 1947; worked in Serbia, currently lives as a pensioner in Zhelino near Tetovo)

"Gurbet is darker then the devil. And the devil is so dark that you couldn't distinguish it from the charcoal. And gurbet is like that - dark." (Man, born in 1968; worked in Germany [1988-1990] and Austria [1991-1998], currently lives in Skopje)

They miss their old friends they have not seen for years. This apartness begets a feeling of estrangement and oblivion:

"Let's say when it is Bayram. The tradition here is: people go to one another and congratulate each other [...] And for nine years that didn't exist for me. I couldn't come, that's how my job was. So, for nine years I did not come for Bayram. People become estranged, your old friends already have new friends, they have other life projects etc. [...] When we come back here, they say: 'Here come the tourists'! We are foreigners there and tourists here. So, you are nowhere, when you are on gurbet, you are nowhere." (Man, born in 1968; worked in Germany [1988-1990] and Austria [1991-1998], currently lives in Skopje)

Thus, the actual points of reference of these Albanian migrants are their places of origin and especially their families living there; moreover they rely on their economic support. In all collected stories worries about the parents, wife, children and other relatives can be found:

"You think of your parents because they rely on you. Because when you go abroad, you have a family and you have to help them. And you constantly think of it - how are they, what are they doing, is anyone sick or not [...] When you have a dream at night - you immediately call - what is happening, is anyone ill?" (Man, born in 1968; worked in Germany [1988-1990] and Austria [1991-1998], lives in Skopje)

"As a rule all Albanians do it in this manner, even to this day - they work in order to send money here! The life abroad is not important for us. We are strongly connected to the family. It is not important for me to be happy and to have a good life abroad, if my family suffers here. So, for us it is more important that one of us be there and supports the whole family than that we are all here and do not work." (Man, born in 1963; worked in Germany [1985-1998], currently lives in Zhelino near Tetovo) 
Money earned abroad is regularly sent to the relatives for covering primary vital needs - food, medicine, clothing, and housing. An important priority for many families was also the expansion of living space - they purchase land, build new family houses, improve the overall infrastructure of the place of origin (Markov 2013: 251-255). Often considerable resources are expended on community rituals such as weddings (see Pichler 2010) or circumcisions. Only a small part is invested in business undertakings, but they are mostly just small firms based on family and kinship relations.

In the early migratory stage (but in some cases even today) earned money was sent to the male head of the family household, who was in charge of controlling the finances:

"Then [in the 1970s] there was a huge family, probably about 30 people. Uncles, cousins, brothers - all of them under the same roof [...] We, my brothers and I, went abroad in order to earn money. And when we came back each of us gave our earnings to our father. The oldest man held the money. It didn't matter that I was the one earning it - he was the one taking it. He was taking care of our children - deciding whether to go to school or work. He was the chief; he kept the business accounts." (Man, born in 1944; worked in Germany and the USA, currently lives as a pensioner partly in Dologozhda near Struga and partly in the USA)

In this way the migration of one or more household members to Europe functions as income insurance. According to this pattern, when an Albanian man goes abroad to work, ideally he does not go "for himself", but to improve the living conditions of his entire family household (Reineck 1991: 143). The aim expressed by the workers abroad is to spend a certain period of time in the host country and earn enough money necessary for a new beginning for them and their families, and after this to return to their villages in Macedonia, which they perceived as home.

"I had gone there with a goal - what I needed so that I could live here, in my native city, where I was born, where my father was born, and my grandfather. I was there with a specific goal - where should I go, why should I go, what should I do, and how much money do I need? And I didn't come back until I got it, I didn't wanna come back. I said to myself - fine, I need a good gain [...] And now, this is ours, it is private [a small hotel built with earned money]." (Man, born in 1968; worked in Germany [1988-1990] and Austria [1991-1998], currently lives in Skopje)

From a material point of view, in the opinion of men who chose to work abroad alone for a certain period of time, remittances enable wives and children left behind to live in much better conditions than their neighbours who could not rely on such resources. At the same time, this is also a less expensive option than taking the fam- 
ily abroad, a process which would incur higher expenses, especially when this extra money can be saved for the future return home:

"If you want to work and save up some money - you can't do that with your family along. There is no chance. If you live with four other men in the same lodging your expenses will be lower, since you will share the rent, so you will be earning more. This was how I lived - with two other men - one from Kosovo, the other from Albania. It was very good, because I had the opportunity to save up 20,000 euro. My brother, for example, has his family along and his monthly wage is 3,000 euro, and he is barely saving up 2,000 euro for the whole year." (Man, born in 1979; worked in Italy [2004-2007], currently lives in Skopje)

The second set of factors is sociocultural in nature: the fear of assimilation and the risk of losing the Albanian identity, language and culture along the generations. Consequently, instead of bringing them to Europe, these men make every endeavour to secure financial stability and good education for their children, who live in the native place:

"While I was in Austria, I met some people who had been there since 1968. Until 1980 they had been alone. Then they had decided to take their family with them. I saw their grandchildren - they spoke German, even among themselves. They did not speak their mother tongue. That's why I did not want to take my children along with me. All the time you communicate only with Austrians and little by little you lose your mother tongue. So, the second or the third generation has already been assimilated." (Man, born in 1968; worked in Germany [1988-1990] and Austria [1991-1998], currently lives in Skopje)

Sometimes even men living with their wives decide to return with the whole family to Macedonia when their children reach school age:

"I didn't plan for us to stay there. I didn't want my children to go to school there. I took them to learn Albanian, not German. Because of that I sent them back here. I saw others there - they had married to Swiss or Italian, and the child became Italian or Swiss." (Man, born in 1955; worked and lived with his family in Switzerland [1988-1999], currently they live in Tetovo)

These men who prefer to leave their wives and children in the native place comment with irritation the growing cases of family migration during the last two decades. The appearance of "them" (those working and living abroad) and "us" (who have been on gurbet, but have come back) is indicative:

"In the last 15-20 years, they started bringing their children abroad. They enrolled the children in German schools and they graduated there. They 
even started buying houses abroad. Those who have already lived there are emigrants. If their children go to school or were born there, they are not there on gurbet. I was on gurbet! They don't know what the gurbet is! And here they come like tourists." (Man, born in 1962; worked in Switzerland [1979-1986], currently lives in Zhelino near Tetovo)

\section{Narratives concerning the migrants' settlement abroad}

For many Albanian migrant labourers, it turned out that achieving the desired objective was not that easy for various reasons (due to the above-mentioned discouraging economic and political situation in Macedonia, as well as more restrictive migration policies in Western European countries). Thus, the return was constantly delayed and many of them worked abroad for two or more decades. They were afraid that if they returned to Macedonia they would no longer be able to re-migrate to Western Europe. Often, especially since family reunion has become human right in the receiving states, Albanian male workers were accompanied by their spouses and/or children in their more prolonged stay.

On the other hand, growing up during the 1970s-1980s period in families with absent migrant fathers influenced the decision of many of my respondents to take their families with them when migrating, giving their own children what they saw as a better life in a family environment:

"But since 1990s they started taking the families abroad. Through the years, another mentality has developed. The old father returns here after 30 years of work in Germany, Austria, but he had already lost his life. People have begun to think otherwise - so, why should I maltreat my wife and children leaving them on their own? Thereby we started taking them abroad." (Man, born in 1965 in Dologozhda; currently lives with his family in Austria)

There are also many personal motives which affect the decision on family reunion abroad, such as certain marital and inter-generational conflicts. Besides, women and children experience a very difficult social and psychological crisis during separation. There also are frequent conflicts between migrants' wives and their in-laws over the use of remittances, especially for those women living in extended families. Economic prosperity and individual independence from patriarchal and community authority play a key role. The ideal case in which a migrant from an extended family goes abroad to work and does not go "for himself" and his nuclear family, but to improve the living conditions of the entire family household, is increasingly fading. Migration enables a man to provide wellbeing for himself without having to support the larger kin network. It calls into question the traditional ideal of life devoted to the collective interests of the extended family. Since the late 1980s and the early 1990s, many 
Albanian migrants have chosen to secure a better life for their spouse and children, often taking them abroad (Reineck 1991: 143). One of my interlocutors explained:

"No matter whether you liked it or not - you had to obey your father, because he was the oldest man. Such was our tradition. And actually we respected each other much more. [This lasted] probably until 20 years ago. And after that you take your family abroad and you don't need to be obedient any more. The old people don't have that influence any more. The children are independent from their parents and do not pay much attention to them, as they used to. They do not give money to the oldest men as well." (Man, born in 1944; worked in Germany and the USA, currently lives as a pensioner partly in Dologozhda near Struga and partly in the USA)

The position of women abroad has also changed: although some stereotypes still persist, reflected in the remarks of some male interviewees who still thought women's place was at home to take care of housekeeping and children, women generally enjoy social freedom, not being under the control of other household members and avoiding the local village community's constant surveillance. Furthermore, there are also respondents who declared that in recent years many of their wives have started to work and to contribute financially to the nuclear family unit:

"Earlier, until 1995-1996, women were not working, but then they began [to work]. It depends on the living standard. The costs are very high, the husband cannot make good money and the wife began working to help him. Thus they can have a better life." (Man, born in 1963; worked in Switzerland [1988-2001], currently lives in Tetovo)

The women who grew up and completed their education abroad experienced perhaps the most important change. Their position, in turn, has strongly affected the change of patriarchal attitudes towards women's role amongst people around them, including men. The words of a young man, whose Albanian wife grew up in Italy, appear to be a good evidence of these new attitudes:

"My wife was there, her father had been working in Italy for many years and he had taken her there as a child. After we married, I also went there [...] I barely speak Italian. But my wife speaks [Italian], she is fluent. What I do not know, my wife knows. She is working in a pasta factory and she found the first job position for me." (Man, born in 1990 in Tearce near Tetovo; currently lives in Italy with his family)

Living abroad with the family changes migrants' priorities which start to differ from the main motivations in the gurbet model: the focus turns towards earning in order to provide for the nuclear family abroad, while sending remittances to the villages of origin takes second place (cf. Akkaya and Soland 2009: 8). 
"In the recent years, our people started buying flats or even building houses in Switzerland. We have citizenship, we already live there. I still think of return after I retire, it is still in my head. But do you know where the problem is? My daughter has a Swiss passport, she is studying there and after she graduates she would have a good salary in Switzerland. And if I invest money there, how can I return? [...] In my opinion to build a big house of three-four storeys here is useless since you don't live here. If you want - build a storey or buy small flat, just for holiday." (Man, born in 1965 in Dologozhda; currently lives with his family in Switzerland)

Collected ethnographic data confirm the statement of Bashkim Iseni that there are different indicators pointing towards a shift in priorities - the strong propensity for naturalization, the acquisition of real estate abroad, the decrease in real estate investments in areas of origin, the increase of Albanian small and medium-sized enterprises owned abroad, and investment in the offspring's education in the country of residence (Iseni 2013: 234).

These migrants typically don't return after their retirement. They have raised their children abroad, and some of them even have grandchildren born in the receiving countries. According to my interlocutors, their children have broader social contacts and a diverse friendship environment, they are provided with better education and have numerous opportunities for professional development in comparison to their own. Although their visit to the country of origin, at least once a year still, appears to be a rule carrying the meaning of going back "home", at retirement age both men and women don't want to permanently go back to their places of birth in Macedonia; instead they prefer to stay in order to live closer to their children and grandchildren:

"It is very difficult for me to return. Because my whole family is there and if I come back with my wife here, all of my children will stay there. What are we going to do here, two old people? You will stay for a month or two and you will immediately begin to think about there. It is very hard for us. We did not think about that when we went on gurbet. When we left, we aimed to work for one or two years, to earn some money, to build a house, just to stabilize, and to come back. But this did not happen." (Man, born in 1954 in Tearce near Tetovo; went to Switzerland in 1980 and took his family there in 1986)

Return is even less desirable for women who, as a result of living abroad, enjoy more freedom, especially with regard to constant compliance to other members of the extended household, as well as the surveillance and supervision by the local community. They fear that returning would restrict their freedom, even in older age. Similarly, the idea of returning does not appeal much to the second generation - migrants' offspring. Paradoxically, regardless of this fact, a large part of them 
continues to maintain a strong sense of belonging to their ethnic Albanian identity: mixed marriages are still an exception and those who were born in Germany, Austria or Switzerland return to Macedonia to find spouses. The everlasting flow of new migrants to areas already inhabited by Albanians who are second and even third generation has a double impact. On the one hand, clubs and organizations in these countries support easier settlement and employment for the newcomers. On the other hand, new migrants carry with them elements of specific local Albanian culture - language, culinary, customs, religious rituals, behavioural habits of their birthplaces, etc.

In this way many of the migrants' descendants still remain related to their places of origin and local communities. For many of them these localities were destinations for childhood summer holidays or places to find a spouse. However, their parents' home villages and Macedonia as a whole are not seen as a place for living. The ongoing socioeconomic underdevelopment and instability is often mentioned as a cause. They fear integration and adaptation problems in case they "return", as well as the lack of opportunities they are so accustomed to abroad (for similar findings see Vathi 2011). Zurich, Munich or Vienna are the places where they were born, raised, and educated. They have their friends and established working positions there, and the real home for them is there:

"I am a pensioner now and I come every year and I remain for five-six months, I like my native village. But my children... they come rarely. They do not like the mentality here. In the Balkans people cheat and lie more and they don't like this, they don't accept it. They have an American mentality. And they can come for a short time, for several days, but they don't want to live here." (Man, born in 1944; worked in Germany and the USA, currently lives as a pensioner partly in Dologozhda near Struga and partly in the USA)

"They will have another mentality. There is nothing attractive for them here anymore. I see my sister's daughters - when they come here, they don't want to stay for a long time. Every day they ask: 'Mummy, when are we going home?' They don't have acquaintances here, nobody knows them. You belong where your friends are. If you send me to the end of the world, I will come back here, I was born here, here is my family, and here are my friends. But those who were born there, they are different - they have citizenship there, they are educated there, and after university, they started immediately working there [...]" (Man, born in 1962; worked in Switzerland [1979-1986], currently lives in Zhelino near Tetovo) 


\section{Conclusion}

Albanian migrants from Macedonia offer an interesting case study regarding the continuity and the shifts which characterise their migratory processes. Different and even opposite migratory strategies (due to residence) have evolved over time. In the 1960s and 1970s, a sizable proportion of male guest workers left their families behind in Macedonia in order to secure better living conditions for them, which meant sending remittances to their areas of origin, building homes and securing the future of their families there. The transformation of the European migratory policy in the 1980s toward immigrant integration, along with the ongoing chronic political, economic and social problems in Macedonia, was the context in which a growing number of people reoriented their migratory projects toward settling abroad. The nature of their transnational practices also changed; today they and their descendants are less connected to the places of origin and better integrated into the host countries. As a result of the diversification of the migrant experience, the understandings and perceptions of home are changing. Many Albanians, especially from the second generation, associate their home with the place abroad, where they were born and/or educated, where they work and plan to set up their families. An important point worth mentioning is that, during the last three decades, "family migration" and settlement abroad have existed simultaneously with the temporary migration of single men (gurbet model). Therefore, both categories of narratives are often interlacing and sometimes the differentiation is blurred, although they were separated in order to facilitate their analysis.

All of these processes and developments are clearly expressed by the Albanian migrants (temporary workers abroad and people settling with their families there). The profound study of continuities and shifts in migration patterns and trends through the people's narratives, concerning their personal life experience, is an appropriate approach which offers the researchers interesting scholarly opportunities. It contributes to a better understanding of the life choices the migrants make and the meanings they invest in their daily routines. 


\section{REFERENCES}

Akkaya, Gülcan and Bernhard Soland. 2009. The Impact of the Emigration of Albanian Migrants on Their Home Region of Tetovo. A Qualitative Exploratory Research Study in the Region of Tetovo, Macedonia. Brief Summary of Final Report. Luzern: University of Applied Sciences and Arts.

Castles, Stephen and Mark J. Miller. 2003. The Age of Migration. International Population Movements in the Modern World. New York: Palgrave Macmillan.

Fassmann, Heinz and Ursula Reeger. 2008. "Austria. From Guest Worker Migration to a Country of Immigration". Ideas Working Paper 1. http://www.idea6fp.uw.edu.pl/ pliki/WP1_Austria.pdf (last access 8 November 2017).

Gross, Dominique M. 2006. "Immigration to Switzerland. The Case of the Former Republic of Yugoslavia”. World Bank Policy Research Working Paper 3880. http:// www-wds.worldbank.org/external/default/WDSContentServer/IW3P/IB/2006/0 4/06/000012009_20060406092110/Rendered/PDF/wps38800rev0pdf.pdf (last access 8 November 2017).

Hristov, Petko. 2015. "The Balkan Gurbet. Traditional Patterns and New Trends". In Migration in the Southern Balkans. From Ottoman Territory to Globalized and Nation States. Hans Vermeulen, Martin Baldwin-Edwards and Riki van Boeschoten, eds. IMISCOE Research Series. Dordrecht: Springer, 31-46.

Ivanović, Vladimir. 2012. Geburtstag pišeš normalno. Jugoslovenski gastarbajteri u SR Nemačkoj i Austriji 1965-1973 [You Write Geburtstag Normally. Yugoslav Guest Workers in the Federal Republic of Germany and Austria 1965-1973]. Beograd: Institut za savremenu istoriju.

Iseni, Bashkim. 2013. "Albanian-Speaking Transnational Populations in Switzerland. Continuities and Shifts". Southeast European and Black Sea Studies 13/2: 227243.

Јанеска, Верица. 2001. Современите мегународни миграуии. Емиграуијата од Република Македонија и соиио-економскиот развој [Contemporary International Migration. Emigration from the Republic of Macedonia and Socioeconomic Development]. Скопје: Економски институт.

Константинов, Аушко. 1964. Печалбарство. Аисертација. [Economic Migration. PhD thesis]. Битола.

King, Russell. 2012. Theories and Typologies of Migration. An Overview and a Primer. Malmö: Malmö University, Willy Brandt Series of Working Papers in International Migration and Ethnic Relations 3/12.

Lieblich, Amia, Rivka Tuval-Maschiach and Tammar B. Zilber. 1998. Narrative Research. Reading, Analysis and Interpretation. London: Sage.

Markov, Ivaylo. 2010. "Labour Migration of the Albanians from Macedonia. Some Aspects and Perspectives of Their Studying". In Balkan Migration Culture. Historical and Contemporary Cases from Bulgaria and Macedonia. Petko Hristov, ed. Sofia: Paradigma, 299-324. 
Markov, Ivaylo. 2012. "Kurbet among Albanians during the Ottoman Period. Characteristics and Destinations". In Travaux de symposium international "Le livre. La Roumanie. L'Europe". Quatrième Edition, 20-23 Septembre 2011. Bucarest: Editura Biblioteca Bukurestilor, 275-285.

Markov, Ivaylo. 2013. "Migration, Remittances and Socio-Cultural Dynamics. The Case of Albanians from the Republic of Macedonia". Southeast European and Black Sea Studies 13/2: 245-264.

Novinšćak, Karolina. 2009. "The Recruiting and Sending of Yugoslav Gastarbeiter to Germany. Between Socialist Demands and Economic Needs". In Transnational Societies, Transterritorial Politics. Ulf Brunnbauer, ed. München: Oldenbourg, 121-143.

Palairet, Michael. 1987. "The Migrant Workers of the Balkans and Their Villages (18th Century - World War II)". In Handwerk in Mittel-und Sudosteuropa. Mobilität, Vermittlung und Wandel im Handwerk des 18. bis 20. Jahrhunderts. Klaus Roth, ed. München: Südosteuropa-Gesellschaft, 23-46.

Pichler, Robert. 2010. "Migration, Ritual and Ethnic Conflict. A Study of Wedding Ceremonies of Albanian Transmigrants from the Republic of Macedonia". Ethnologia Balkanica 13: 211-229.

Reineck, Janet S. 1991. The Past as Refuge. Gender, Migration, and Ideology among the Kosova Albanians. PhD thesis. Berkeley: University of California.

Roberts, Brian. 2002. Biographical Research. Buckingham: Open University Press.

Thompson, Paul. 1978. The Voice of the Past. Oral History. Oxford: Oxford University Press.

United Nations. 2006. Trends in Total Migrant Stock. 2005 Revision. New York: Department of Economic and Social Affairs, Population Division.

United Nations. 2016. International Migration Report 2015. Highlights. New York: Department of Economic and Social Affairs, Population Division.

Vathi, Zana. 2011. "A Context Issue? Comparing the Attitude towards Return of the Albanian First and Second Generation in Europe". Journal of Mediterranean Studies 20/2: 343-364. 